\title{
Viability of Ethical Business Practices in Today's Competition in India: An Empirical Review
}

\author{
Rohit Kanda \\ Research Scholar, Faculty of Management Studies, PAHERU Udaipur, India
}

\begin{abstract}
Ethics concern an individual's moral judgments about right and wrong. The decision to behave ethically is a moral one; employees must decide what they think is the right course of action. Today, it seems like the larger a corporation gets, the slimier their actions become. Making money is not wrong in itself. It is the manner in which some businesses conduct themselves that brings up the question of ethical behavior (Maitland, 1994). Money is the major deciding factor (Seglin, 2003). If a company does not adhere to business ethics and breaks the laws, they usually end up being fined (Drucker, 1981). Many companies broken anti-trust, ethical and environmental laws and received fines worth millions (Velasquez, 1983). Now in this review focusing on Indian business houses we will study the status of ethics in their practices and the need and possibility of revival there.
\end{abstract}

Keywords: Ethics, Ethical Business Practices, Indian Governance, Reforms Sought, Way Ahead

\section{Introduction}

Ethics concern an individual's moral judgments about right and wrong. Decisions taken within an organization may be made by individuals or groups, but whoever makes them will be influenced by the culture of the company. The decision to behave ethically is a moral one; employees must decide what they think is the right course of action. This may involve rejecting the route that would lead to the biggest short-term profit. Unethical behavior or a lack of corporate social responsibility, by comparison, may damage a firm's reputation and make it less appealing to stakeholders. Profits could fall as a result. Toyota made a huge and unethical failure in 2010 when they basically betrayed their promise as a company by ignoring safety concerns and delaying recall investigations. After confronted with safety concerns regarding faulty brakes and sticking pedals in 2009, Toyota said that phasing in side airbags saved $\$ 124$ million and 50,000, the cost of what it would have taken to recall and fix vehicles.

Infamous Halliburton is one of the world's largest oil corporations worldwide, operating in over 80 countries. They have been accused, multiple times, of engaging in business transactions with countries with which trades are prohibited by the US government. It has been accused of overbilling the US army for food and oil supplies during the Iraq war, 2003. It has also been accused of covering up violations of corruption laws and misleading investigators and so on. Halliburton faces multiple additional lawsuits for endangering employees, endangering National Guard members by unknowingly exposing them to hazardous chemicals, and over oil spills said to be the result of careless and unsafe practices.

Another example is of iPhone. Everyone wants an iPhone and no one really cares if it were made by tiny child slaves who are forced to work in dangerous conditions, inhaling cancerous vapors, for 10 hours a day, seven days a week. The controversy began in 2006 and is still happening today. And while Apple has made efforts to branch out and use some different manufacturers to produce their products, unethical Foxconn is still their go-to company. Besides using Foxconn, Apple co-founder Steve Wozniak claimed that Apple was engaging in unethical tax practices by utilizing an Irish tax loophole to avoid paying billions in taxes on international sales.

All these reveals us that many a times business houses got involved in unethical business practices to increase their profits or to improve their capability in market. Such practices did throughout the world. This urges out the need for studying out the matter. Now in this review focusing on Indian business houses we will study the status of ethics in their practices and the need and possibility of revival there.

\section{Review of Literature}

The Greeks and Romans defined Ethos as the compilation of the usages, ideas, standards, and codes by which a group lives'. Business ethics is a form of applied ethics (Broni, 2010) that examines ethical principles and moral or ethical problems that arise in a business environment (Solomon, 1991). It applies to all aspects of business conduct (Baumhart, 1968; Ferell, \& Fraedrich, 1997; Singer, 1991) and is relevant to the conduct of individuals and business organizations as a whole (Bernard, 1972; Donaldson, 1982).

Applied ethics is a field of ethics that deals with ethical questions in many fields such as technical, legal, business and medical ethics (Preston, 1997). Business ethics consists of a set of moral principles and values (Jones, Parker, \& Bos, 2005:17) that govern the behavior of the organization with respect to what is right and what is wrong (Badiou, 2001; Seglin, 2003). It spells out the basic philosophy and priorities of an organization in concrete terms (French, 1979; French, 1995). It also contains the prohibitory actions at the workplace (Collier, \& Esteban 2007; Duska, 1999). With time, certain moral philosophies have helped in the evolution of four basic concepts of ethics. They are deontologism, relativism, egoism, and utilitarianism (Kotsiris, 2003). This research will try to sheds light on the practical existence of basic principles of business ethics and these aforesaid concepts. Business ethics is the behavior that a business adheres to in its daily dealings with the world (Borgerson, \& Schroeder, 2008). The ethics of a particular 


\section{International Journal of Science and Research (IJSR) ISSN (Online): 2319-7064 \\ Index Copernicus Value (2013): 6.14 | Impact Factor (2014): 5.611}

business can be diverse (Solomon, 1983). They apply not only to how the business interacts with the world at large, but also to their one-on-one dealings with a single customer (Solomon, 1991).Many businesses have gained a bad reputation just by being in business (Carr, 1968). To some people, businesses are interested in making money, and that is the bottom line (Solomon, 1983). It could be called capitalism in its purest form (Antoniou, 2008). Making money is not wrong in itself. It is the manner in which some businesses conduct themselves that brings up the question of ethical behavior (Maitland, 1994). Good business ethics (American Psychological Association, 1992, 1999, 2001) should be a part of every business (Preuss, 1997). There are many factors to consider (Michalos, 1995). When a company does business with another that is considered unethical, does this make the first company unethical by association (Kahneman, Knetsch, \& Thaler, 1986; Velasquez, 1983)? Some people would say yes, the first business has a responsibility (Michalos, 1995) and it is now a link in the chain of unethical businesses (Kanungo, \& Mendoca, 1996). Many global businesses, including most of the major brands that the public use, can be seen not to think too highly of good business ethics (Maitland, 1994). Many major brands have been fined millions for breaking ethical business laws (Cory, 2005). Money is the major deciding factor (Seglin, 2003). If a company does not adhere to business ethics and breaks the laws, they usually end up being fined (Drucker, 1981). Many companies broken antitrust, ethical and environmental laws and received fines worth millions (Velasquez, 1983). The problem is that the amount of money these companies are making outweighs the fines applied (Green, 1991). The profits blind the companies to their lack of business ethics, and the money sign wins (DeGeorge, 1999). A business may be a multi-million seller, but does it use good business ethics and do people care (French, 1979)? There are popular soft drinks, fast food restaurants, and petroleum agencies that have been fined time and time again for unethical behavior (Harwood, 1996). Business ethics should eliminate exploitation, from the sweat shop children who are making sneakers to the coffee serving staff that is being ripped off in wages. Business ethics can be applied to everything from the trees cut down to make the paper that a business sells to the ramifications of importing coffee from certain countries (Aiken, 1991).In the end, it may be up to the public to make sure that a company adheres to correct business ethics (Clarke, 2004). If the company is making large amounts of money, they may not wish to pay too close attention to their ethical behavior (Behrman, 1988). There are many companies that pride themselves in their correct business ethics (Stark, 1993), but in this competitive world, they are becoming very few and far between (Knight, 1980). In the increasingly consciencefocused marketplaces of the 21 st century, the demand for more ethical business processes and actions (known as ethicism) is increasing (Donaldson, 1982). Simultaneously, pressure is applied on industry to improve business ethics through new public initiatives and laws (e.g. higher luxury taxes). Businesses can often attain short-term gains by acting in an unethical fashion (Sunstein, 2002). However, such behaviors tend to undermine the economy over time (Velasquez, 1983). Business ethics can be both a normative and a descriptive discipline (Abrams, 1954). As a corporate practice and a career specialization, the field is primarily normative. In academia descriptive approaches are also taken. Historically, interest in business ethics accelerated dramatically during the 1980s and 1990s, both within major corporations and within academia (Cory, 2005). For example, today, most of the major corporates, on their websites, lay emphasis on commitment to promoting noneconomic social values under a variety of headings. Business management scholars have been searching for a business case for CSR since the origins of the concept in the 1960s. The CSR of the 1960s and 1970s was motivated by social considerations, not economic ones. Only in the past 20 to 25 years, the concept of business ethics consulting has developed, originally provided on an ad hoc basis by academics that were doing research into business ethics, but since the 1990s there has been an increase in the number of firms that provide formal ethics consulting services. In the recent decade, many authors and researchers has given their opinion on the subject. Some eminent ones of these are as follows:

Campbell \& Malan (2002) suggests that Ethical business is good business, especially if you want to stay in business. "Recent corporate collapses, as a result of poor corporate governance, both locally and internationally, have once again emphasized the importance of doing business ethically," "Good ethics makes good business sense," stresses Malan. "Long-term profitability depends on sustainability, and to ensure sustainability in the twenty-first century you need to focus on integrated financial, ethical and environmental performance at the same time - the so-called 'triple bottom line'," he argues. he further adds that 'basic ethical infrastructure' involves such things as official company codes of conduct and ethics and official company confidential reporting lines to allow 'whistle-blowers' to report wrongdoing. "Codes of ethics are often not supported by training in ethical practices for employees, it is not clear whether confidential reporting lines are used effectively and, in many cases, no senior manager is clearly designated to handle ethics issues," he reports."Companies need to refocus on the ethics function and ensure that their basic infrastructure is backed up by effective ethics management practices," he states. He supported his opinion by second King Report on Corporate Governance, which clearly states that companies should demonstrate a commitment to organizational integrity.

Blowfield (2003) in his research embellishes that we need a more rigorous approach to understanding whose rights are being considered and whose are being denied. There is evidence that certain issues will be overlooked or excluded from standards in the future because they cannot be codified or measured. What is more, others have de facto been removed from negotiation as a condition of business participation in ethical sourcing. Put another way, businesses' expectations regarding their engagement may be that civil society and government will leave unquestioned such rights as the freedom to trade, to invest and disinvest and to defer to market mechanisms as the arbiter of fair price.

Mulla (2003) comments upon that the efficacy of corporate initiatives in the ethical regard in Indian Environment remains to be seen. Dunning, \& Wales (2004) while giving 


\section{International Journal of Science and Research (IJSR) \\ ISSN (Online): 2319-7064 \\ Index Copernicus Value (2013): 6.14 | Impact Factor (2014): 5.611}

their opinion on Global Capitalism says that If global capitalism is to be both economically viable and socially acceptable, each of its four constituent institutions must not only be technically competent, but also be buttressed and challenged by a strong moral ethos. Labbai (2007), further extending the approach, argues that companies must adopt and disseminate a written Code of Ethics, build a company tradition of ethical behavior, and hold its people fully responsible for observing ethical and legal guidelines. Whereas, Seshadri, Raghawan, \& Hedge (2007) expresses their view that business ethics are also about creating an ethically sound working environment within organization and about modeling ethical behavior by leadership. Their research suggests that it makes good long term business sense to be ethical. Freeman, York, \& Stewart (2008) exclaim that Human life is rich and complex and not reducible solely to an economic calculation. Businesses can and often do stand for something more than profitability. Some, like IBM, stand for creating value for customers, employees, and shareholders. On this behalf, they had defined a few of Green principles at large towards the stakeholders.

Pivato, Misani, \& Tencati (2008) illustrate the role of trust as a mediating variable which shapes the relationship between CSR activities and firm performance. Barnett (2007) set out the construct of stakeholder influence capacity, which illustrates how situational contingencies may affect the impact of CSR activities on firm financial performance. It is critical to apply the contingency perspective as suggested by Barnett (2007) and account for the role of mediating variables as proposed by Pivato (2008) in the exploration of the relationship between CSR and firm financial performance. Pal (2009) further expands the view stating that through the positive linkage between directors' remuneration \& revenue from additionality, the ethical arm of corporate governance would further be strengthened. Further, Carroll, \& Shabana (2010) exemplifies that the broad view of the business case for CSR enables the firm to enhance its competitive advantage and create win-win relationships with its stakeholders, in addition to realizing gains from cost and risk reduction and legitimacy and reputation benefits, which are realized through the narrow view. The broad view enhances the acceptance of the business case for CSR, because it acknowledges the complex and interrelated nature of the relationship between CSR and firm financial performance. Recognizing this complexity translates into a clearer understanding of the impact of CSR initiatives on firm financial performance while accounting for the effects of mediating variables and situational contingencies. To formulate a successful CSR strategy, firms must understand that the benefits of CSR are dependent on mediating variables and situational contingencies.

Velentzas, \& Broni (2010) expresses that nowadays ethics in business are obligated because many businessmen are only interested in making money despite the ethical costs or the harm they would probably cause to people or even to nature. Jalil, Azam, \& Rahman (2010) bring out a more comprehensive perspective. As per them, ethics and ethical behavior are issues which are increasingly being focused on the business community today. People are becoming more concerned about what is actually happening in business organizations in the name of competition, growth, and profitability. As per their research, it is very essential to have a code of business ethics in every business organization and this code of business ethics must be implemented in the organization in objective and effective way. Whereas, Smart, Barman, \& Gunasekera (2010) observes that strong ethical policies that go beyond upholding the law can add great value to a brand, whereas a failure to do the right thing can cause social, economic and environmental damage, undermining a company's long-term prospects in the process. They recommends that Corporate communications and reporting on sustainability need to do more than just pay lip service to the green agenda, and hence, ethics must be embedded in business models, organizational strategy and decision making processes. Mishra \& Sharma (2010) Extending the aspect disserts that an Effective CSR Policy within specific industries and companies is becoming increasingly accepted, but its implementation varies all across.

Tonello (2011) interprets that in the last decade; in particular, empirical research has brought evidence of the measurable payoff of corporate social responsibility (CSR) initiatives to companies as well as their stakeholders. Companies have a variety of reasons for being attentive to CSR. It had to do with the long-standing divide between those who, like the late economist Milton Friedman, believed that the corporation should pursue only its shareholders' economic interests and those who conceive the business organization as a nexus of relations involving a variety of stakeholders without which durable shareholder value creation is impossible.

He asserts Another impetus that Even though CSR came about because of concerns about businesses' detrimental impacts on society, the theme of making money by improving society has also always been in the minds of early thinkers and practitioners: with the passage of time and the increase in resources being dedicated to CSR pursuits, it was only natural that questions would begin to be raised about whether CSR was making economic sense. He recognizes that In addition to the guardians of companies' financial well-being, other groups such as Shareholders, Social activists, Governmental bodies, Consumers, are well concerned with the wellness of entity in the pursuit of their respective combined interest. Considering such counterparts, positive effects of CSR on firm performance includes Reducing Costs and Risks, Equal employment opportunity policies and practices, Energy-saving and other environmentally sound production practices, Community relations management, Gaining Competitive Advantage, Developing Reputation and Legitimacy, Seeking Win-Win Outcomes through Synergistic Value Creation.

James, Jr. (2013) acclaims that business organizations that contribute to the increase in the density of local food production, they identify the emerging business practices, ethics principles, and competition in this regard and new cooperatives will be better aware of viable business models based on ethics. Donaldson describes that Business ethics are business actions in light of some aspect of human value. There is no viable universal standard that can be applied to 


\section{International Journal of Science and Research (IJSR) \\ ISSN (Online): 2319-7064 \\ Index Copernicus Value (2013): 6.14 | Impact Factor (2014): 5.611}

everyone. This separates them from what would have been the ethos or mores of the people today. Extending the approach, Nainawat, \& Meena (2013) addresses Ethics as the first line of defense against corruption. Further, Rebelly, \& Ragidi (2014), in their study based upon NTPC, asserts that Companies must make profit to survive with growth, but within the ethical bounds.

Hussaini (2014), in her research on Top Indian IT Companies, opines that there is a strong need to formally address the ethical issues with all seriousness. She further adds that the Ethical and Compliance Policies are not in place in Indian IT Firms and there is a strong need to improve up to reach up to global standards, if they wish to succeed in global market over a long term. A standard for measuring and reporting ethical behavior in business should be adopted to validate the claims of it being ethical. Sharma (2014) further exclaims that Ethical Codes in the Indian Context have not been subjected too much scrutiny. She disserts that most Indian Codes, at present, are heavily rule based \& complex, reducing the ease. She prospects that Indian Ethics' Code will move from mere compliance to a new value based sphere. Kain, \& Sharma (2014) further recommends that by adopting the NHRC ( National Human Rights Commission of India) Code of Ethics, Indian Enterprises can lead hundreds of MNCs that have adopted the United Nation's "Protect, Respect and Remedy" Framework. Whereas, Mishra, Dalvi, Sahni, \& Verma (2014) observes that most of the well established firms have a well written ethical code of conduct and they strictly follow it. These firms are successively increasing their participation in the CSR activities.

Kshatriya (2014) exclaims that business world across globe has started looking east, particularly India, for Ethical Business Models. He suggests that a culture that is conservative in monetary terms attaches a very high value to created wealth, in turn, leading to business practices bringing change in lives of many and ensuring the process of wealth creation. Patel \& Schaefer (2014) further argue that choices about specific ethical behaviors do not depend on static and universal set of rules. They suggest that four predominant types of ethical behaviors coexist in every social system, linked to the dynamic coexistence of the four solidarities or cultural patterns, especially in Indian context. It implies that managers from one national background show greater ethical awareness than that of others having a variant. All these works reveals us the importance of ethics and depicts out the need of ethical business practices to upgrade the position, but due to competitive business environment finding it hard to do. At the end of this chapter, we will only say that this not a exhaustive list of the research work happened and only commits to bring a brief picture on the research works done by some of the most eminent.

\section{Research Gap}

As described in the literature review, good work is being done at the world level. In case of Asian perspective a less number of researches had found taken place. But we have found a least or negligible no. of research work done on the phenomenon with regard to India in a rigorous manner. Only a few reports and / or papers are found in this behalf. In this research, we will try to cover the same research gap by using different data sources relevant to the study.

\section{Summary Conclusions}

Business ethics can be applied to everything from the trees cut down to make the paper that a business sells to the ramifications of importing coffee from certain countries. There are many companies that pride themselves in their correct business ethics, but in this competitive world, they are becoming very few and far between. In the increasingly conscience-focused marketplaces of the 21 st century, the demand for more ethical business processes and actions is increasing.

Choices about specific ethical behaviors do not depend on static and universal set of rules. The ethics of a particular business can be diverse. They apply not only to how the business interacts with the world at large, but also to their one-on-one dealings with a single customer. Further no one strategic business model, code or approach is applicable in this world in all respects in all business entities. More empirical and theoretical research work is needed in the sphere, to firm up the exact modular relationship between the societal culture and business ethics.

Many organizations are choosing to make a public commitment to ethical business by formulating codes of conduct and operating principles. Ethics and ethical behavior are issues which are increasingly being focused on the business community today. A growing number of organizations are constantly surveying and evaluating the unethical practice in business organizations worldwide. It is empirically proved that ethical practices in business organizations help to create favorable relationships with other organizations and can also establish long-term positive relationships with existing and potential future customers.

Businesses can often attain short-term gains by acting in an unethical fashion. However, such behaviors tend to undermine the economy over time. Recent corporate collapses, as a result of poor corporate governance, both locally and internationally, have once again emphasized the importance of doing business ethically. Many global businesses, including most of the major brands that the public use, can be seen not to think too highly of good business ethics and thereby, fined millions for breaking ethical business laws.

Long-term profitability depends on sustainability, and to ensure sustainability in the twenty-first century you need to focus on integrated financial, ethical and environmental performance at the same time - the so-called 'triple bottom line'. We need a more rigorous approach to understanding whose rights are being considered and whose are being denied.

An Effective CSR Policy within specific industries and companies is becoming increasingly accepted, but its implementation varies all across. In the last decade, empirical research has brought evidence of the measurable payoff of corporate social responsibility (CSR) initiatives to companies as well as their stakeholders. Positive effects of 


\section{International Journal of Science and Research (IJSR) \\ ISSN (Online): 2319-7064}

Index Copernicus Value (2013): 6.14 | Impact Factor (2014): 5.611

CSR on firm performance includes Reducing Costs and Risks, Equal employment opportunity policies and practices, Energy-saving and other environmentally sound production practices, Community relations management, Gaining Competitive Advantage, \& Many More.

Ethical Codes in the Indian Context have not been subjected too much scrutiny. As reviewed by some researches, Ethical and Compliance Policies are not in place in Indian IT Firms and there is a strong need to improve up to reach up to global standards, if they wish to succeed in global market over a long term. Companies able to innovate new solutions and values in a socially responsible way, are most likely to succeed. Through the positive linkage between directors' remuneration \& revenue from additionality, the ethical arm of corporate governance would further be strengthened. Corporate communications and reporting on sustainability need to do more than just pay lip service to the green agenda, and hence, ethics must be embedded in business models, organizational strategy and decision making processes. The efficacy of corporate initiatives in this regard in Indian Environment remains to be seen. Till then Employees' personal initiative and dynamic leadership for a sustainable moral ethical character will work for.

\section{References}

[1] Abrams, F. (1954). Management responsibilities in a complex world, Business Education for Competence and Responsibility. T. H. Carroll, University of North Carolina Press, Chapel Hill, NC.

[2] Aiken, L.R. (1991). Psychological testing and assessment (7th Ed.). Allyn and Bacon, Boston.

[3] American Psychological Association (1992). Ethical principles of psychologists and code of conduct. American Psychologist, 47: 1597-1611.

[4] American Psychological Association (1999). The rights and responsibilities of test takers: Guidelines and expectations. American Educational Research Association, Washington DC

[5] American Psychological Association (2001). Ethical principles of psychologists and code of conduct. Draft for comment. The Monitor of Psychology, 32 (2): 7789.

[6] Antoniou, A.S. (2008). Business Ethics (I-II) [in Greek]. Sakkoulas, Athens.

[7] Badiou, A. (2001). Ethics: An Essay on the Understanding of Evil. Verso, London.

[8] Barnett, M.L. (2007). Stakeholder influence capacity and the variability of financial returns to corporate social responsibility. Academy of Management Review, 32: 794-816.

[9] Baumhart, R. (1968). An Honest Profit: What Businessmen Say About Ethics and Business. Holt, Rinehart \& Winston, New York.

[10] Behrman, J.N. (1988). Essays on Ethics in Business and the Professions. Englewood Cliffs, Prentice Hall, NJ.

[11]Bernard, W. (1972). Morality. Harper \& Row.

[12]Blowfield, M. (2003). Ethical Supply Chains in the Cocoa, Coffee and Tea Industries. GMI, 43: 15-24.

[13] Borgerson, J. L., \& Schroeder, J. E. (2008). Building an Ethics of Visual Representation: Contesting Epistemic
Closure in Marketing Communication. Cutting Edge Issues in Business Ethics. Springer, Morland \& Werhane, Boston, 87-108.

[14] Broni, G. (2010). Ethics in Business [in Greek]. IuS.

[15] Campbell, K., \& Malan, D. (2002). Business ethics essential for viability. Creamer Media's Engineering News, Apr.

[16] Carr, A. (1968). Is Business Bluffing Ethical? Harvard Business Review, Jan-Feb.

[17] Carroll, A.B., \& Shabana, K.M. (2010). The Business Case for Corporate Social Responsibility: A Review of Concepts, Research and Practice. International Journal of Management Reviews, 85-105.

[18] Clarke, T. (Ed), (2004). Theories of Corporate Governance: The Philosophical Foundations of Corporate Governance. Routledge, London - New York.

[19]Collier, J., \& Esteban, R. (2007). Corporate social responsibility and employee commitment. Business Ethics: A European Review, 16(1): 19-33.

[20] Cory, J. (2005). Activist Business Ethics, 9: 11. Springer, Boston.

[21] DeGeorge, R.T. (1999). Business Ethics. Prentice Hall, 5th ed. (1st ed. N.Y.: Macmillan, 1982).

[22] Donaldson, T. (1982). Corporations and Morality, 36. Englewood Cliffs, Prentice Hall.

[23] Drucker, P. (1981). What is business ethics? The Public Interest, 63: 18-36.

[24] Dunning, J.H., Wales, P. (2004). Making Globalization Good: The Moral Challenges of Global Capitalism. PhilPapers.

[25] Duska, R. (1999). Employee Rights. A companion to business ethics, 257-268. R.E. Frederic, Blackwell, Oxford.

[26]Ferell, O., \& Fraedrich, J. (1997). Business ethics: ethical decision making and cases. Haugton Mifflin.

[27] Freeman, R.E., York, J.G., \& Stewart, L. (2008). Environment, Ethics, and Business. Bridge Paper: Business Roundtable Institute for Corporate Ethics.

[28]French, P.A. (1979). The Corporation as a Moral Person. American Philosophical Quarterly, 16: $207-$ 215.

[29] French, P.A. (1995). Corporate Ethics. Harcourt Brace, ICSA Publishing, Fort Worth, Florida.

[30] Green, R. (1991). When is "Everyone's Doing It" a Moral Justification? Business Ethics Quarterly, 1 (1): 75-93.

[31] Harwood, S. (1996). Business as Ethical and Business as Usual. The Thomson Corporation, Belmont, CA.

[32] Hussaini, N. (2014). Corporate Ethics of Top IT Companies in India, 2-21. TMBU Bihar, India.

[33]Jalil, M.A., Azam, F., \& Rahman, M.K. (2010). Implementation Mechanism of Ethics in Business Organizations. International Business Research, Oct.: $1-11$.

[34] James, H.S.J. (2013). The Ethics and Economics of Agrifood Competition. Agriculture Journal.

[35] Jones, C., Parker, M., \& Bos, R. (2005). For Business Ethics: A Critical Text, 17. Routledge, London.

[36] Kahneman, D., Knetsch, J., \& Thaler, R. (1986). Perceptions of Unfairness: Constraints on Wealth Seeking. American Economic Review, 76: 724-741.

\section{Volume 5 Issue 2, February 2016}




\section{International Journal of Science and Research (IJSR) \\ ISSN (Online): 2319-7064 \\ Index Copernicus Value (2013): 6.14 | Impact Factor (2014): 5.611}

[37]Kain, P., \& Sharma, S. (2014). Business Ethics as Competitive Advantage for Companies in the Globalized Era. Journal of Management Sciences and Technology, 3(1): 39-46.

[38] Kanungo, R., \& Mendoca, M. (1996). Ethical Dimensions of Leadership. SSBE Sage Series on Business Ethic, 81. Sage Publications Inc., Thousand Oaks, CA.

[39] Knight, F. (1980). The Ethics of Competition and Other Essays. University of Chicago Press.

[40] Kotsiris, L. (2003). On Business Ethics [in Greek].

[41] Kshatriya, A. (2014). Culture \& Ethics: A Perspective on Indian Business Values, 2. http://ssrn.com/abstract/=1695281 Accessed 10 April 2015.

[42]Labbai, M.M. (2013). Social Responsibility and Ethics in Marketing. International Marketing Conference on Marketing \& Society, Apr.: 17-27. IIMK Kerala, India.

[43] Maitland, I. (1994). The Morality of the Corporation: An Empirical or Normative Disagreement? Business Ethics Quarterly, 4: 445-458.

[44] Michalos, A. (1995). A Pragmatic Approach to Business Ethics. Sage Publications, London.

[45] Mishra, A.K., \& Dalvi, B.B. - Sahni, S. - Verma, V. (2014). Ethical Considerations in Business Decision Making in Indian Companies, 18. IITB Maharashtra, India.

[46] Mishra, N., \& Sharma, G. (2010). Ethical Organization and Employees. Asian Journal of Management Research, 79.

[47] Mulla, Z. (2003). Corporates in India Cannot Afford to be Ethical. Management Labour Studies, February, 17.

[48] Nainawat, R., \& Meena, R. (2013). Corporate Governance and Business Ethics. Global Journal of Management and Business Studies, 3(10): 1085-1088.

[49] Pal, A.M. (2009). Ethics in Corporate Governance: A Critical Review. Journal of Business \& Economic Issues, 1(1): 84.

[50] Patel, T., \& Schaefer, A. (2014). Making Sense of the Diversity of Ethical Decision Making in Business: An Illustration of the Indian Context, 6-33.

[51] Pivato, S., Misani, N., \& Tencati, A. (2008). The impact of corporate social responsibility on consumer trust: the case of organic food. Business Ethics: A European Review, 17: 3-12.

[52] Preston, D. (1997). Can Business Ethics Really Exist? Computers and society, Mar.: 6-11.

[53] Preuss, L. (1997). A moral handrail for business: the need for a contextual model of business ethics, Business Ethics, 41: Moore

[54] Rebelly, H., \& Ragidi, V. (2014). Ethical Issues in Business \& Corporate Governance: A Case Study of NTPC-Ramagundam. International Journal of Marketing, Financial Services \& Management Research, 1(5): 62-67.

[55] Seglin, J.L. (2003). The right thing: conscience, profit and personal responsibility in today's business. Rollinsford, Spiro Press, NH.

[56] Seshadri, D.V.R., Raghavan, A., \& Hedge, S. (2007). Business Ethics: The Next Frontier for Globalizing Indian Companies. Vikalpa, 32(3): 61.
[57] Sharma, M. (2014). Ethics Statements on Web sites of Indian Companies. Research and Publications, W.P. No. 2014-05-01: 15.

[58] Singer, P. (Ed.) (1991). A Companion to Ethics. Blackwell \& Malden, MA.

[59] Smart, V., Barman, T., \& Gunasekera, N. (2010). Incorporating ethics into strategy: developing sustainable business models. CIMA Discussion Paper, Oct.: $1-15$.

[60] Solomon, R. (1991), Business Ethics. A Companion to Ethics, 354-365. Singer \& Malden, Blackwell, MA.

[61] Solomon, R.C. (1983). Above the Bottom Line: An Introduction to Business Ethics. Harcourt Trade Publishers.

[62] Stark, A. (1993). What's Wrong With Business Ethics? Harvard Business Review, 71 (3): 38-48.

[63] Sunstein, C.R. (2002), Switching the Default Rule. New York University Law Review, 77: 106-134.

[64] Tonello, M. (2011). The Business Case for Corporate Social Responsibility. My Wordpress Blog, Jun.

[65] Velasquez, M. (1983). Why Corporations Are Not Morally Responsible For Anything They Do. Business \& Professional Ethics Journal, 2, pp. 1-18.

[66] Velentzas, J., \& Broni, G. (2010). Ethical dimensions in the conduct of business: business ethics, corporate social responsibility and the law. The "ethics in business" as a sense of business ethics. International Conference on Applied Economics, 795-819. 